\title{
17: 77261425-77279553
}

National Cancer Institute

\section{Source}

National Cancer Institute. 17:77261425-77279553. NCI Thesaurus. Code C42463.

Physical location of HGS_Gene 